\title{
水利水电施工项目固定单价物资采购合同供应商调价应对参考
}

\author{
梁忠民 \\ 中国水利水电第十二工程局有限公司 \\ DOI:10.32629/hwr.v3i12.2570
}

[摘 要] 水利水电工程物资采购项目,由于部分标的物资不在造价信息目录范围、或信息价与市场实际行情不符不具备参考价值等原因,采用 了固定单价合同。履约中标的物资市场价格上涨,供应商据此提出调价要求。此类问题采购单位可采取哪些应对措施? 本文就此提出以下处理 意见以供参考。

[关键词] 固定单价；合同终止；备选供应商；履约担保；供应商评价

\section{1 处理原则不予调价}

根据物资采购合同条款, 采购项目既然已经约定为固定单价, 供应商 报价时应充分考虑到材料价格上涨的风险, 双方默认已包含在材料综合单 价中。合同条款是双方自愿, 经协商达成的统一共识, 对双方都是公平的, 均应诚信履约。所以采购单位应坚持原则, 要求继续按照合同条款执行, 不予调价。

\section{2 对于供应商消极供货的应对}

如材料价格出现大幅单边上涨行情, 市场价格远高于合同价格, 供应 商确实无法履约, 双方应友好协商, 约定合同终止缓冲期限, 供应商应保障 合同终止缓冲期间的材料供应, 采购单位可视供应商保供情况酷情扣除履 约保证金。

供应商不签订终止协议, 又不能保证供应甚至涉嫌恶意拖延供应, 可 依据采购合同违约情形及责任相关条款处理,一般应在采购合同中约定： “... 乙方 (供货方) 未按本合同规定的日期按期提供货物及附加服务... 所提供货物的品牌、数量、质量、型号、技术性能和技术特性不符合双方 约定要求. . . 乙方迟延交货的, 应按延迟交货合同价款 $* \%$ / 日向甲方 (采购 方) 支付违约金, 并承担因货物延误给甲方造成的损失。

\section{3 启用备选供应商或重新组织采购}

3. 1 双方终止合同后, 采购单位可与备选供应商进行商务和技术条 款确认, 如同时满足以下两点, 重新定标批复后, 可与备选供应商签订供 应合同:

（1）备选供应商确认原报价文件继续有效, 或在原报价文件基础上承 诺更优惠的条件; (2) 采购单位经市场调查, 认为备选供应商的报价符合当 前市场行情。

3. 2 如采购项目评标报告未推荐备选供应商, 或备选供应商不再响应 原报价文件, 或采购单位认为有必要进一步扩大范围更充分竞价, 可根据 未完供应物资的预算总额, 组织开展相应层级的集中采购。

\section{4 防范措施}

4. 1 严格执行合同范本。以笔者所在单位为例, 合同金额 100 万元人民 币以上的设备物资采购项目, 各二级单位均应参考公司设备物资合同示范 文本 (修订版) 签订合同。该合同范本依据国家现行法律法规及时修订, 经 公司法律事务部、财务产权部、设备物资部等多个部门会审通过后发布执 行。合同范本关于标的物质量要求、检验与验收、结算支付、违约情形及 责任、争议解决等事项, 提出了全面、细致的要求, 为合同顺利履约奠定良 好的法律依据。
4. 2 履约担保。履约担保是最对供应商直接的经济制约措施, 采购单位 可根据供应商的履约情况酷情扣除。关于物资采购及工程建设领域履约担 保的相关规定：履约保证金不得超过中标合同金额的 $10 \%$; 已经缴纳履约 保证金的, 建设单位不得同时预留工程质量保证金; 保证金总预留比例不 得高于工程价款结算总额的 $3 \%$ 。笔者认为, 不同违约情形使用相应的保证 金约束, 物资采购宜同时收取履约保证金和质量保证金。保证金收取金额 越高, 对供应商制约力度越强, 但也并非越高有利, 考虑资金占用成本等因 素, 相应费用可能在报价过程转移到材料综合单价中, 反而提高了材料成 本。履约保证金、质量保证金可在采购文件中具体约定, 建议保证金总金 额不超过合同金额的 $3 \%$ 。

4. 3 供应商评价。采购单位应该建立供应商评价制度, 供应商履约过程 中有违规、违纪及不良履约行为的供应商, 将视情况给予一定时限或永久 的禁入。笔者所在单位供应商管理制度要求, 根据供应商履约情况进行动 态管理和年度评价, 被列入不合格供应商黑名单后, 将在股份公司集采平 台公示, 无法参与中国电建集团范围内所有工程的设备物资采购项目。采 购单位面对供应商调价诉求, 宜本着诚信为本合作共赢的理念积极沟通, 并将本公司供应商履约评价相关管理制度充分宣贯, 争取按合同条款继续 履约。

4. 4 推荐备选供应商。采购项目在推荐供应商阶段, 建议评标委员会 (谈 判小组、询价小组) 要推荐备选供应商名单, 尽量采取一首两备模式。备选 机制可以让中标供应商产生一定的危机意识, 对中标供应商良好履约有一 定的督促作用。如中标供应商未签订合同或履约终止, 可及时启动备选程 序。相比重新组织采购, 可节省大量时间、人力成本, 对工期紧急项目作用 尤为显现。

\section{5 综述}

固定单价物资采购项目, 定标时一定要做好履约防范, 有 “备” 无患; 供应商提出调价的应对, 首先据理力争按原合同执行, 其次启用备选供应 商, 最后重新组织采购。灵活运用履约担保和供应商评价制度, 确保物资正 常供应, 保障施工生产需要。

\section{[参考文献]}

[1]周海婷.关于《招标投标法》的探讨[J].建筑管理现代化,2000(03):18. [2]戴国华.建筑企业应收质量保证金面临的风险及应对策略[J].财务 与会计,2013(04):25-27.

[3]郑王成,张丰毅.工程保证金的制度弊端及改革建议[J].建筑,2015(3):26. 